\title{
Low serum vitamin-D status is associated with high prevalence and early onset of type-1 diabetes mellitus in Kuwaiti children
} (1) CrossMark

\author{
Majedah A. Rasoul ${ }^{1,2}$, Maria Al-Mahdi ${ }^{3}$, Hessa Al-Kandari ${ }^{4}$, Gursev S. Dhaunsi ${ }^{1,2}$ and Mohammad Z. Haider ${ }^{1 *}$
}

\begin{abstract}
Background: Type 1 diabetes mellitus (T1DM) is highly prevalent in Kuwait with incidence of around 40.1/100,000 individuals. Evidence indicate that vitamin D plays an important role in modulating the immune system and could thus impact the onset and high prevalence of T1DM. We report serum vitamin D levels in Kuwaiti children with T1DM and non-diabetic controls to explore its relationship with prevalence and onset of the disease.

Methods: This study included 216 Kuwaiti Arab children with T1DM. The diagnosis of T1DM was based on the ISPAD criteria. The control subjects (204 Kuwaitis) were age and gender matched, healthy, non-diabetic, and had no close relative with T1DM. Vitamin D levels were determined in serum using an enzyme immunoassay (EIA) method.

Results: The age of onset of T1DM was $<4 y$ in $20 \%$ of the T1DM cases, between 4 and $6 y$ in $28 \%$ cases and $>6 y$ in $52 \%$ patients. In T1DM patient group, $84 \%$ subjects were found to be deficient in serum vitamin D level compared to $77 \%$ of the controls $(p=0.046)$. Collectively, the deficient and insufficient vitamin D status was detected in $99 \%$ of the T1DM patients compared to $92 \%$ of the controls $(p=0.027)$. The mean serum vitamin D levels were found to be significantly different in early onset cases (age $<4 y$ ) compared to the late onset sub-group $(p=0.001)$. A significant correlation was found between some elements of socioeconomic status, SES (i.e. parent's profession and family's income) and lower vitamin D levels in Kuwaiti T1DM children. There was no significant difference between mean serum vitamin D levels during winter and summer months in the T1DM patients.

Conclusions: The proportion of cases with a deficient vitamin D status was significantly high in Kuwaiti T1DM children compared to the controls. The serum vitamin D levels were found to be significantly different in early onset and late onset T1DM patients. Therefore, serum vitamin D status can be considered an important contributor in high prevalence of T1DM in Kuwaiti children.
\end{abstract}

Keywords: Type-1 diabetes, Vitamin D, Kuwait, Deficiency

\section{Background}

The incidence of type-1 Diabetes Mellitus (T1DM) has been increasing in Kuwait over the past three decades [1]. Shaltout et al. [2] reported a four-fold increase in the incidence of T1DM $(15.4 / 100,000)$ in the $0-14 y$ agegroup compared to $3.96 / 100,000$ individuals reported from Kuwait in 1980s [3]. In the period between 1992 and 93 , the incidence was found to be $12.8 / 100,000$ in $0-5$ y age group; $15.1 / 100,000$ in $5-9$ y group and 18.3 /

\footnotetext{
*Correspondence: haider@hsc.edu.kw

${ }^{1}$ Department of Pediatrics, Faculty of Medicine, Kuwait University, PO Box 24923, Safat 13110, Kuwait

Full list of author information is available at the end of the article
}

100,000 in the $10-14 y$ age group respectively [2]. Later in 2002, Shaltout et al. [1] reported an incidence of 20.1/ 100,000 Kuwaiti children in the age range $0-14$ y. These authors also reported that in the 1980s, the incidence of T1DM in Kuwait was in the same range as 'low incidence' countries $(3.96 / 100,000)$, however, during the subsequent 10 years period, in the 1992-93, it increased almost four times to $15.4 / 100,000$ children [3] and was similar to that reported from 'high incidence' European countries $[4,5]$. Patterson et al. [6] have documented the worldwide estimates of type 1 diabetes and reported an incidence of 22.3/100,000 in Kuwait. The most recent incidence data of T1DM in Kuwait comes from the 
National Type 1 Diabetes Registry (established in 2011); according to this source the incidence of T1DM in Kuwait is 40.1 per 100,000 individuals (Shaltout AA, Rasoul MA, Al-Khawari M; unpublished data). Rasoul et al. [7] also reported a very high incidence 20.1/100,000 during the period between 1995 and 99 in a hospital based study of the Kuwaiti T1DM children from a high population density area. Unlike other complex/chronic diseases of the childhood, a wide variation in the incidence of T1DM has been found in different world populations. The highest incidence has been reported from Finland and Sardinia [8] and low incidence was noted in Mexico, China, Korea and Japan [4]. The basis for such a wide variation in the incidence of T1DM in different populations and in the same population over time has been an area of intensive investigation. It has been suggested that environmental factors, nutritional pattern and life style changes have played a significant role in genetically susceptible population/ethnic groups which has resulted in rapid increase in the incidence of T1DM.

T1DM is considered to result from a complex interplay between predisposing genes, immune system mediators and environmental factors. An immune-mediated destruction of insulin-producing beta-cells in the pancreatic Islets of Langerhans is thought to result in T1DM. The activation of auto-reactive lymphocytes and the cytokine-induced apoptosis of pancreatic beta-cells play a major role in the etiology of T1DM. A variety of evidence indicate that vitamin-D plays an important role in modulating the immune system and could thus impact the onset of T1DM. Vitamin D is a potent immune-modulator, regulating cell proliferation and differentiation, lymphocyte activation and cytokine production [9]. 1,25-Dihydroxyvitamin- $\mathrm{D}_{3} \quad\left[1,25(\mathrm{OH})_{2} \mathrm{D}_{3}\right]$ inhibits lymphocyte activation and affects other elements of the immune system, such as cytokine and immunoglobulin production, as well as major histocompatibility (MHC) class-II and cluster of differentiation-4 (CD4) expression [10]. Recent evidence indicate that the production and degradation of $1,25(\mathrm{OH})_{2}$ vitamin-D is a major signaling component in both innate [11] and adaptive [12] immune systems. However, the relationship between circulating levels of $25(\mathrm{OH})$-vitamin D and immune responsiveness is largely undefined [10]. In NOD mice, it has been shown that the development of diabetes can be prevented by administration of vitamin D [13]. Studies in humans have indicated that vitamin D supplementation in early childhood decreases the risk of T1DM and that intake of vitamin $\mathrm{D}$ in pregnancy may prevent the appearance of islet autoantibodies in the offspring [14-16]. The effect of vitamin D in T1DM was first proposed based on the observation that its incidence rates were negatively correlated with sunlight exposure, resulting in higher incidence at higher altitude [17], and the distinctive seasonal pattern in T1DM incidence with largest proportion of cases diagnosed in winter and lowest during summer [18]. In this prospective study, we report serum vitamin-D levels in Kuwaiti children with T1DM and healthy controls to explore its relationship with the disease.

\section{Methods}

A total of 216 newly diagnosed T1DM patients were recruited from three major hospitals (Mubarak Al-Kabeer, Adan and Farwania). The inclusion criteria used was according to ISPAD/WHO protocol: i) diagnosis by a physician as diabetic; ii) placed on a daily dose of insulin before the 15th birthday and a Kuwaiti national resident in the area at the time of first insulin administration. In addition to the 216 T1DM patients a total of 204 nondiabetic controls were also studied. The selection of controls was random, they were all Kuwaiti Nationals and were matched for age, gender and ethnicity. The control subjects were healthy volunteers and a trained Diabetes specialist made a thorough assessment of their health status. This study has been approved by the Joint Committee for Protection of Human Subjects in Research of the Faculty of Medicine, Kuwait University and Kuwait Institute of Medical Specializations (KIMS), Ministry of Health, Kuwait. Informed consent was obtained from the study subjects and/or their parents as per regulations of the Ethics Committees.

\section{Collection and processing of samples}

Approximately $5 \mathrm{ml}$ blood was collected from all the study subjects in appropriate tubes for subsequent laboratory analyses. The blood was drawn from patients when they were first diagnosed with T1DM. The serum was isolated from samples collected in plain tubes and stored at $-30{ }^{\circ} \mathrm{C}$ for subsequent analyses.

\section{Analysis of the biochemical parameters}

Serum glucose levels were measured by routine work-up of T1DM patients by using glucose oxidase method, hemoglobin A1c (HbA1c) levels were measured by high performance liquid chromatography (HPLC), serum $\mathrm{Ca}^{2}$ ${ }^{+}$and phosphate concentration were determined using spectrophotometric methods.

\section{Measurement of 25-Hydroxyvitamin-D (25-OH Vitamin-D)}

The levels of 25-Hydroxyvitamin-D in the serum were determined in T1DM patients and non-diabetic controls (216 patients and 204 controls respectively) by using a non-radioactive Enzyme Immunoassay kit (EIA kit, Immuno-Diagnostic Systems Ltd. Boldon, UK, www.idsplc.com). This method uses 'Direct' assay technology, eliminates the solvent precipitation and 
centrifugation steps thus resulted in automation of the ELISA procedure. It has been shown to possess excellent sensitivity $(5 \mathrm{nmol} / \mathrm{L}, 2 \mathrm{ng} / \mathrm{mL})$ from a small sample size $(25 \mu \mathrm{l})$ and a wide assay range $(6-360 \mathrm{nmol} / \mathrm{L}, 2.4-$ $144 \mathrm{ng} / \mathrm{mL}$ ). Furthermore, this method eliminated the need for using a radioactive tracer. Appropriate controls were included in all assays for standardization and quality control. Random samples were re-assayed in a quality control setting at Hospital laboratory to check the efficacy of the assay kits.

The vitamin-D levels in serum were considered deficient when $<21 \mathrm{ng} / \mathrm{ml}$; insufficient when $21-29 \mathrm{ng} / \mathrm{ml}$ and sufficient when $>29 \mathrm{ng} / \mathrm{ml}$ as per guidelines of the Task Force of the Endocrine Society, 2011 [19]. The vitamin-D levels were determined in T1DM patients recruited in different months of the year and data was pooled from summer months (April-September) and winter months (October-March) for making comparisons.

\section{Detection of autoantibodies}

Three autoantibodies, Islet Cell autoantibody (ICA), Insulin (INS) and glutamic acid decarboxylase (GAD) were detected in the serum samples from T1DM patients at the hospital laboratories by radioimmunoassay using commercial kits (Cisbio Assays, Codolet, France; www.cisbio.com).

\section{Documentation of socioeconomic status of the families with T1DM children}

In order to obtain an assessment of the socioeconomic status (SES) of the Kuwaiti families with T1DM children, information was collected using a standardized questionnaire at the time of their recruitment in the study according to previously published strategy [20, 21]. The socioeconomic parameters/indicators included educational background of the parents, their profession and total monthly income of the family [20].

\section{Statistical analysis}

The data was analyzed using the Statistical Package for the Social Sciences version 23 (SPSS, Chicago IL, USA). The serum vitamin D levels in different groups of subjects were presented as mean $\pm \mathrm{SD}$ and comparisons between study groups were made by using Fisher's Exact test, chi-square or student $t$-test. The $p$-values were considered significant when $<0.05$. In appropriate cases, odds ratios were calculated at $95 \%$ confidence interval.

\section{Results}

The characteristics of T1DM patients and controls are presented in Table 1. The Male/Female distribution was 104-112 in the T1DM patients group while it was 10698 in the controls (the difference not statistically significant; $p=0.49$; Table 1 ). The mean age of subjects in the T1DM patients group was $115.05 \pm 38.44$ months and that of the control group was $115.18 \pm 32.7$ months respectively (the difference was not statistically significant). The age of onset of T1DM was below $4 y$ in $42 / 215$ (20\%) patients; between 4 and 6y in 61/215 (28 \%) patients and >6y in 112/215 (52 \%) patients respectively (Table 1). Collectively, $48 \%$ of the total number of T1DM patients included in this study can be considered to have an early onset of the disease while $20 \%$ of the total number fall in the very early onset category (Table 1). In the T1DM patients, 32/179 (18\%) had an affected sibling; in 74/206 (36 \%) cases, the parents were consanguineous while in 75/196 (38 \%) cases even the grandparents were consanguineous (Table 1).

In 167/216 (77 \%) T1DM patients, mean HbA1c was between 7 and $10 \%$ (53-86 IFCC or $\mathrm{mmol} / \mathrm{mol}$ ) while 49/216 (23 \%) T1DM patients had their HbA1c >10\%. All the control subjects had $\mathrm{HbA1c}$ in the normal range i.e. below $6 \%(42 \mathrm{mmol} / \mathrm{mol})$.

Insulin Cell auto-antibody (ICA) was detected in 124/ 209 (59 \%) T1DM patients. INS autoantibody was found

Table 1 Characteristics of Kuwaiti T1DM patients $(n=216)$ and controls $(n=204)$

\begin{tabular}{|c|c|c|c|c|c|}
\hline & T1DM patients & Controls & $p$-value & $O R^{a}$ & $\mathrm{Cl}^{\mathrm{b}}$ \\
\hline \multicolumn{6}{|l|}{ Gender } \\
\hline Males & 104 & 106 & 0.49 & 0.86 & $0.585-1.259$ \\
\hline Females & 112 & 98 & 0.49 & 1.165 & $0.794-1.709$ \\
\hline \multicolumn{6}{|c|}{ Age at onset of T1DM (No. of subjects) } \\
\hline$<4 y$ & $42 / 215(20 \%)$ & & & & \\
\hline $4-6$ y & $61 / 215(28 \%)$ & & & & \\
\hline$>6 y$ & $112 / 215(52 \%)$ & & & & \\
\hline \multicolumn{6}{|l|}{ Family history in T1DM patients ${ }^{c}$} \\
\hline Having an affected sibling & $32 / 179(18 \%)$ & & & & \\
\hline Parents consanguineous & $74 / 206$ (36 \%) & & & & \\
\hline Grandparents consanguinity & 75/196 (38 \%) & & & & \\
\hline
\end{tabular}

${ }^{\mathrm{a}} \mathrm{OR}$ odds ratio; ${ }^{\mathrm{b}} \mathrm{Cl} 95 \%$ confidence interval; ${ }^{\mathrm{C}}$ This information was not available for some of the cases 
in $157 / 209$ (75\%) of the patients while GAD was detected in 188/211 (89 \%) T1DM cases respectively. In $87 / 209$ (42\%) patients, all three autoantibodies were detected. In 6/209 (3 \%) patients, no autoantibody was detected and of these patients who did not have any autoantibody, 5/209 (2 \%) had HbA1c above $6.0 \%$.

The mean serum vitamin D level in Kuwaiti T1DM patients was $13.84 \pm 6.66 \mathrm{ng} / \mathrm{ml}$ and in the controls it was $14.98 \pm 10.4 \mathrm{ng} / \mathrm{ml}(p=0.19)$. The status of serum $25-\mathrm{OH}$ vitamin-D in T1DM patients and non-diabetic controls is presented in Table 2. In the T1DM patients group, 182/216 (84 \%) were found to be 'deficient' in their vitamin-D status compared to $158 / 204$ (77\%) of the controls ( $p=0.046$; OR 1.66; Table 2). The vitaminD status was 'insufficient' in 31/216 (15\%) T1DM patients as compared to $29 / 204$ (14 \%) of the controls $(p=0.93)$. In only $3 / 216(1 \%)$ of the T1DM patients, the vitamin-D status was in the 'sufficient' range, compared to $11 / 204$ (5 \%) of the controls $(p=0.027$; Table 2). When the 'deficient' and 'insufficient' subgroups were taken together $(213 / 216,99 \%)$ and compared to the controls (187/204, $92 \%)$, the difference in the two study groups was found to be statistically significant ( $p=0.027, \mathrm{OR}, 4.176$; Table 2$)$.

The mean serum vitamin $\mathrm{D}$ levels detected in the three sub-groups of T1DM patients on the basis of age of onset of the disease are presented in Table 3. The difference in the mean vitamin D level was found to be statistically significant between the early-onset sub-group (age of onset $<4 y$ ) and the late onset sub-group (age of onset $>6 \mathrm{y}), p=0.001$ (95\% CI, 1.43 to 5.96 ).

The socioeconomic status of the family was evaluated by obtaining information on the educational background of parents, their profession and the family's total monthly income. Each of these indicators were then correlated with the mean vitamin $\mathrm{D}$ level in children with T1DM. The serum vitamin D level in Kuwaiti children with T1DM did not show any significant correlation with the educational background of the parents (Table 4). The data on correlation between mean serum vitamin D levels in T1DM children and parent's profession and the family's total monthly income is presented in Table 5. A statistically significant correlation was noted between

Table 2 The vitamin-D status in Kuwaiti T1DM patients and controls (according to The Endocrine Society Guidelines; [19])

\begin{tabular}{llllll}
\hline Sub-groups & $\begin{array}{l}\text { T1DM patients } \\
(N=216)\end{array}$ & $\begin{array}{l}\text { Controls } \\
(N=204)\end{array}$ & $p$-value & $\mathrm{OR}^{\mathrm{a}}$ & $\mathrm{Cl}^{\mathrm{b}}$ \\
\hline Deficient & $182(84 \%)$ & $158(77 \%)$ & 0.046 & 1.66 & $1.02-2.701$ \\
Insufficient & $31(15 \%)$ & $29(14 \%)$ & 0.93 & 0.977 & $0.565-1.689$ \\
Sufficient & $3(1 \%)$ & $11(5 \%)$ & 0.027 & 0.239 & $0.0658-0.872$ \\
$\begin{array}{l}\text { Defficient + } \\
\text { Insufficient }\end{array}$ & $213(99 \%)$ & $187(92 \%)$ & 0.027 & 4.176 & $1.147-15.202$ \\
${ }^{a}$ OR odds ratio; ${ }^{\mathrm{b}} \mathrm{Cl} 95 \%$ confidence interval & & & \\
\hline
\end{tabular}

Table 3 Serum vitamin D levels ( $\mathrm{ng} / \mathrm{ml}$ ) in Kuwaiti T1DM patients divided into sub-groups on the basis of age of onset of the disease

\begin{tabular}{|c|c|c|c|c|}
\hline \multicolumn{5}{|c|}{ Mean serum vitamin D levels \pm SD* $(\mathrm{ng} / \mathrm{ml})$} \\
\hline $\begin{array}{l}<4 \text { years }(a) \\
(N=44)\end{array}$ & $\begin{array}{l}2-6 \text { years }(b) \\
(N=55)\end{array}$ & $\begin{array}{l}>6 \text { years }(\mathrm{C}) \\
(\mathrm{N}=115)\end{array}$ & $p$-value & $\mathrm{Cl}^{* *}$ \\
\hline $16.313 \pm 6.877$ & $14.56 \pm 5.946$ & $12.616 \pm 6.566$ & & \\
\hline \multicolumn{5}{|c|}{ Statistical comparison between patient sub-groups } \\
\hline \multicolumn{2}{|c|}{ Sub-group (a) with (b) } & & 0.18 & -8.30 to 4.336 \\
\hline \multicolumn{2}{|c|}{ Sub-groups (a) with (c) } & & 0.001 & 1.43 to 5.96 \\
\hline \multicolumn{2}{|c|}{ Sub-group (b) with (c) } & & 0.069 & -0.15 to 4.03 \\
\hline
\end{tabular}

${ }^{a} S D$ standard deviation; ${ }^{b} \mathrm{Cl} 95 \%$ confidence interval

the mean vitamin D level of T1DM children when the father's profession was 'semi-skilled' and 'Office workers' $(p=0.05)$ and when their profession was 'semi-skilled' and 'professional' ( $p=0.007$; Table 5$)$. In the case of mother's profession, a statistically significant correlation was noticed in T1DM patient's vitamin D levels when the mother's profession was 'laborer' compared to 'Office worker' $(p=0.03)$; between 'semi-skilled and 'skilled' $(p=0.002)$ and between 'office worker' and 'skilled' category $(p=0.045$; Table 5$)$. In the case of total monthly income, a statistically significant difference was found only between family's income KD 1000 and income between KD 1000-2000 $(p=0.046)$. The differences between other income-groups were not statistically significant.

The seasonal distribution of mean serum vitamin-D levels in T1DM patients and controls is presented in Table 6. Serum vitamin D levels from T1DM patients and controls during different months of the year were analyzed after pooling the data from summer months (April-September) and winter months (October-March). The differences between the T1DM patients and controls were not statistically significant in these two subgroups i.e. during the summer months $(p=0.228)$ and the winter months $(p=0.403)$.

\section{Discussion}

The most striking finding in this study is that majority of the Kuwaiti T1DM children were found to be deficient in their serum vitamin-D status (84\%, Table 2). Collectively, the 'deficient' and 'insufficient' vitamin D status was detected in $99 \%$ of the Kuwaiti children with T1DM $(p=0.027$; Table 2$)$. This is very high and somewhat surprising when considered together with the socioeconomic status (SES) of the families with T1DM children. In majority of the T1DM families, the parents were educated (Tables 4 and 5), had a high total monthly income and can be considered affluent. Therefore it appears that lack of awareness or proper attention to health matters by the parents, life style and family 
Table 4 Correlation of serum vitamin D level in Kuwaiti T1DM children with their parent's education level

\begin{tabular}{|c|c|c|c|c|}
\hline \multirow[b]{2}{*}{ Serum vitamin D levels in T1DM children } & \multicolumn{4}{|c|}{ Father's education level } \\
\hline & Illiterate (a) $(N=0)$ & Primary $(b)(N=26)$ & Secondary $(c)(N=78)$ & University $(d)(N=108)$ \\
\hline \multirow[t]{3}{*}{${ }^{\mathrm{a}}$ Mean serum Vitamin D levels (ng /ml) } & - & $13.729 \pm 6.057$ & $13.941 \pm 6.33$ & $13.965 \pm 7.2$ \\
\hline & \multicolumn{4}{|c|}{ Mother's education level } \\
\hline & $(N=3)$ & $(N=14)$ & $(N=50)$ & $(N=143)$ \\
\hline${ }^{a}$ Mean serum Vitamin D levels (ng/ml) & $8.23+6.471$ & $12.898+5.224$ & $14.763+8.373$ & $13.888+6.071$ \\
\hline
\end{tabular}

${ }^{a}$ No statistically significant correlation was found between the mean serum vitamin D levels in Kuwaiti T1DM children and their parent's education level

structure may be the contributing factors in poor vitamin-D status in these Kuwaiti T1DM children. This finding in our study that collectively the 'deficient' and 'insufficient' vitamin D status was found in $99 \%$ Kuwaiti T1DM patients compared to $92 \%$ in the controls (mentioned above) is in sharp contrast to a recent report from Saudi Arabia where the 'deficient' vitamin D status was found in $66.7 \%$ Saudi T1DM patients compared to $41.7 \%$ of the controls [22]. In another report from Saudi Arabia, vitamin D deficiency was detected in $84 \%$ Saudi T1DM children compared to $59 \%$ in the controls [23]. The prevalence of vitamin D deficiency in Kuwaiti T1DM patients and controls was much higher than that reported from similar studies in other World populations [24, 25]. Vitamin D deficiency was found to be $43 \%$ in T1DM patients in a study from Australia [25], $60.5 \%$ in Switzerland [26], $25 \%$ in Italy [27] and $15 \%$ in North America [24]. The report from Qatar [28] on the correlation of vitamin D deficiency with T1DM appear to be somewhat similar to our findings in Kuwait. In that study, vitamin D deficiency was reported in $90.6 \%$ Qatari T1DM children compared to $85.3 \%$ in the controls. In a Swedish study, serum $25(\mathrm{OH})$ vitamin D levels were found to be similar in T1DM patients and controls in a cross-sectional study (sub-optimal in both groups; [29]). Another study from Sweden [30] reported low vitamin D levels in patients aged between 15 and 34 years who were newly diagnosed with T1DM compared to that in the controls. Similar findings have been reported from a study from India in newly diagnosed children and adolescents [31]. It is important to understand the impact of low vitamin D levels in T1DM patients because of its possible effect on the mechanism of autoimmune destruction of the $\beta$-cells. Therefore, determination of vitamin D status especially in newly diagnosed T1DM cases can be of benefit for prevention or delaying the insulin-dependence which can be achieved by supplementation with vitamin $\mathrm{D}$ or its analogues.

The effect of season on the vitamin-D status was evaluated by combining the data on vitamin-D levels in T1DM patients in summer and winter months. There appear to be no correlation between season and the mean vitamin-D levels in Kuwaiti T1DM patients and the controls. This is not surprising when one considers that due to harsh climate, the living in Kuwait is mostly indoors with little or no direct exposure to sunlight. It

Table 5 Correlation of serum vitamin D level in Kuwaiti T1DM children with their parent's profession and total family income

\begin{tabular}{|c|c|c|c|c|c|c|}
\hline & \multicolumn{6}{|l|}{ Father's profession } \\
\hline & $\begin{array}{l}\text { Not employed }(a) \\
(N=22)\end{array}$ & $\begin{array}{l}\text { Laborer (b) } \\
(N=6)\end{array}$ & $\begin{array}{l}\text { Semi-skilled (c) } \\
(N=33)\end{array}$ & $\begin{array}{l}\text { Office worker }(d) \\
(N=86)\end{array}$ & $\begin{array}{l}\text { Skilled (e) } \\
(N=30)\end{array}$ & $\begin{array}{l}\text { Professional }(f) \\
(N=33)\end{array}$ \\
\hline \multirow{3}{*}{$\begin{array}{l}\text { aMean serum vitamin D } \\
\text { levels }(\mathrm{ng} / \mathrm{ml})\end{array}$} & $14.590 \pm 4.788$ & $16.296 \pm 4.876$ & $11.305 \pm 5.921$ & $13.959 \pm 7.238$ & $13.512 \pm 5.172$ & $15.716 \pm 7.658$ \\
\hline & \multicolumn{6}{|l|}{ Mother's profession } \\
\hline & $(N=69)$ & $(N=4)$ & $(N=26)$ & $(N=21)$ & $(N=78)$ & $(N=12)$ \\
\hline \multirow{3}{*}{$\begin{array}{l}{ }^{\mathrm{b}} \text { Mean serum vitamin D } \\
\text { levels }(\mathrm{ng} / \mathrm{ml})\end{array}$} & $13.561 \pm 5.945$ & $18.5 \pm 4.2$ & $10.877 \pm 4.252$ & $12.201 \pm 5.392$ & $15.43 \pm 7.807$ & $13.739 \pm 6.385$ \\
\hline & \multicolumn{6}{|l|}{ Family's total income } \\
\hline & \multicolumn{2}{|l|}{$<\mathrm{KD} 1000, N=4(\mathrm{a})$} & \multicolumn{2}{|c|}{ KD 1000-2000, N=97 (b) } & \multicolumn{2}{|c|}{$>\mathrm{KD} 2000, N=110(\mathrm{c})$} \\
\hline $\begin{array}{l}{ }^{c} \text { Mean serum vitamin D } \\
\text { levels }(\mathrm{ng} / \mathrm{ml})\end{array}$ & $7.795 \pm 0.709$ & & \multicolumn{2}{|l|}{$14.53 \pm 0.619$} & \multicolumn{2}{|l|}{$13.539 \pm 5.615$} \\
\hline \multicolumn{7}{|c|}{$\begin{array}{l}\text { a A statistically significant correlation was detected in serum vitamin D level between groups (c) and (d), } p=0.05) \text { and between groups (c) and (f), } p=0.007 \text { of the } \\
\text { Father's profession } \\
\text { bIn case of 'Mother's profession, statistically significant correlation was found between groups (b) and (d), } p=0.03 \text {; between groups (c) and (e), } p=0.002 \text { and } \\
\text { between groups (d) and (e), } p=0.045 \text { ) } \\
\text { In the case of 'Family's total income, statistically significant correlation was noted only between groups (a) and (b), p=0.046 } \\
\text { The differences between all other groups based on parent's profession and total family income were not statistically significant. The categories of the profession } \\
\text { have been chosen as described previously by Shah et al. [20] in Kuwait for determining the socio-economic status (SES) }\end{array}$} \\
\hline
\end{tabular}


Table 6 Serum vitamin D level (ng/ml; mean \pm SD) detected in summer and winter months in Kuwaiti children with T1DM

\begin{tabular}{lclc}
\hline Months (No. of subjects) & T1DM patients & Controls & $p$-value \\
\hline $\begin{array}{l}\text { aSummer months } \\
\text { (73 patients, 61 controls) }\end{array}$ & $14.51 \pm 7.2$ & $16.36 \pm 9.77$ & 0.228 \\
b Winter months & $13.49 \pm 6.27$ & $14.37 \pm 10.65$ & 0.403 \\
(143 Patients; 137 Controls) & & & \\
\hline
\end{tabular}

${ }^{\mathrm{a}}$ Summer months (April-September); ${ }^{\mathrm{b}}$ Winter months (October-March)

has been suggested in previous reports from the region $[22,29]$ that a strong relationship exists between vitamin D status and the clothing worn. Kuwait is an Arab country in which majority of both males and females wear traditional clothes which leaves very little areas of the body exposed. This coupled with the harsh desert climate (being confined to indoor living) is likely to result in poor vitamin $\mathrm{D}$ status in both the T1DM patients and non-diabetic controls.

Like other studies of this nature, our study has some limitations e.g. possibility of individual variability in nutritional habits and fat proportion in study subjects are difficult to ascertain. However, a stringent evaluation was carried out at the time of recruitment of the study subjects, which minimized the effects of these factors as much as possible.

Another important finding reported in this study is that in the T1DM patients group, $18 \%$ children had another sibling who had the same disease. And in families having T1DM children, $36 \%$ of the parent were consanguineous while in $38 \%$ cases even the grandparents were also related. This phenomenon of inter-family marriages is common in many tribal societies (like in Kuwait) and should be considered an important factor that can significantly impact the 'genetic factors' contributing to onset of T1DM and together with other factors like vitamin $\mathrm{D}$ deficiency can explain its very high incidence $(40.1 / 100,000)$ in Kuwait.

The vitamin-D deficiency can therefore be considered an important factor which has a significant role in high prevalence of T1DM in Kuwait. This highlights an urgent need for launching a campaign for both the care providers and general public to enhance awareness of this problem in order to reduce its negative impact on this highly prevalent disease which places considerable burden on health care system and the community.

\section{Conclusions}

The deficient serum vitamin D status was found to be significantly high in Kuwaiti T1DM patients compared to that in the controls. Mean serum vitamin D levels were significantly different between the early onset T1DM patients and the late-onset cases. A significant correlation was detected between parent's professions, family's income and low vitamin D levels in Kuwaiti T1DM patients.

\section{Abbreviations}

T1DM, type 1 diabetes mellitus; ISPAD, International Society for Pediatric and Adolescent diabetes; CD4, cluster of differentiation-4; HbA1c, hemoglobin A1c; HPLC, high performance liquid chromatography; KIMS, Kuwait Institute for Medical Specializations; EIA, enzyme immunoassay; ELISA, enzyme linked immune-sorbent assay; ICA, Islet cell autoantibodies; INS, insulin autoantibody; GAD, glutamic acid decarboxylase autoantibody; SES, socioeconomic status; SD, standard deviation; Cl, confidence interval; KD, Kuwaiti dinar;

\section{Acknowledgements}

This study was supported and funded by Kuwait University (Project \# MK01/11). The assistance of hospital staff who helped in sample and data collection is thankfully acknowledged. We thank Mrs. Jalaja Sukumaran for technical assistance and Mrs. Asiya Ibrahim for help in statistical analysis.

\section{Funding}

The project was funded by Kuwait University (Project No. MK01/11). The funding body had no role in study design, collection and analysis of data and writing the manuscript.

\section{Availability of data and materials}

The data will not be made available in order to protect the participant's identity.

\section{Author's contributions}

MAR contributed in study design, recruitment and clinical evaluation of study subjects and writing the manuscript. MA and HA recruited subjects for studies, carried out their clinical evaluation, contributed in collection of clinical data and in writing the manuscript. GSD contributed in study design, laboratory analyses and in manuscript writing. MZH along with MAR conceived and designed the study, supervised the laboratory/analytical procedures, compiled and analyzed the clinical and laboratory data and wrote the manuscript. All authors read and approved the final manuscript.

\section{Competing interests}

The authors declare that they have no competing interests.

\section{Consent for publication}

Not applicable.

\section{Ethics approval and consent to participate}

This project was approved by the Joint Committee For Protection of Human Subjects in Research (Ref. No. VDR/JC/116, dated November 3, 2011) by the Kuwait University, Faculty of Medicine and Kuwait Institute of Medical Specializations. The study has been carried out strictly according to the guidelines of the Joint Committee and as per Helsinki Declaration. Informed consent was obtained from all the study subjects for participation in this study.

\section{Author details}

${ }^{1}$ Department of Pediatrics, Faculty of Medicine, Kuwait University, PO Box 24923, Safat 13110, Kuwait. ${ }^{2}$ Department of Pediatrics, Mubarak Al-Kabeer Hospital, Jabriya, Kuwait. ${ }^{3}$ Department of Pediatrics, Adan Hospital, Al-Adan, Kuwait. ${ }^{4}$ Department of Pediatrics, Farwania Hospital, Farwania, Kuwait.

Received: 8 January 2016 Accepted: 17 June 2016

Published online: 16 July 2016

References

1. Shaltout AA, Moussa MAA, Qabazard M, Abdella N, Karvonen M, Al-Khawari $M$, et al. Further evidence for the rising incidence of childhood Type 1 diabetes in Kuwait. Diabet Med. 2002;19(6):522-5.

2. Shaltout AA, Qabazard MA, Abdella N, LaPorte RE, Al-Arouj M, Ben Nekhi A, et al. High incidence of childhood-onset IDDM in Kuwait. Kuwait Study Group of Diabetes in Childhood. Diabetes Care. 1995;18:923-7.

3. Taha T, Moussa M, Rashad A, Fenech F. Diabetes mellitus in Kuwait: incidence in the first 29 years of life. Diabetologia. 1983;25:296-308.

4. Karvonen M, Viik-Kajander M, Moltchanova F, Libman I, LaPorte R, Tumilehto J. Incidence of childhood type-1 diabetes worldwide. Diabetes Care. 2000; 23:1516-26. 
5. Green A, Gale EAM, Patterson CC. Incidence of childhood-onset insulindependent diabetes mellitus: the EURODIAB ACE Study. Lancet. 1992;339: 905-9.

6. Patterson C, Guariguata L, Dahlquist G, Soltesz G, Ogle G, Silink M. Diabetes in the young - a global view and worldwide estimates of numbers of children with type 1 diabetes. Diabetes Res Clin Prac. 2014;103:161-75.

7. Rasoul MA, Al-Qattan H, Al-Haj A, Habib H, Ismael A. Incidence and seasonal variation of type 1 diabetes in children in Farwania area, Kuwait (1995-1999). Diabet Res Clin Prac. 2002;56(1):153-7.

8. Karvonen M, Jantti V, Muntoni S, Stabilini M, Stabilini L, Muntoni SE, et al. Comparison of the seasonal pattern in the clinical onset of IDDM in Finland and Sardinia. Diabetes Care. 1998;21:1101-9.

9. Uitterlinden AG, Fang Y, Van Meurs JB, Pols HA, Van Leeuwen JP. Genetics and biology of vitamin D receptor polymorphisms. Gene. 2004;338:143-56.

10. Thomasset M. Vitamin D, and the immune system. Pathol Biol. 1994;42:163-72.

11. Liu PT, Stenger S, Li H. Toll-like receptor triggering of a vitamin D-mediated human antimicrobial response. Science. 2006;311:1770-3.

12. Mathieu C, Waer M, Laureys J, Rutgeerts O, Bouillon R. Prevention of autoimmune diabetes in NOD mice by 1,25 dihydroxyvitamin D3. Diabetologia. 1994;37:552-8.

13. The EURODIAB Substudy-2 Study Group. Vitamin D supplement in early childhood and risk for type 1 (insulin-dependent) diabetes mellitus. Diabetologia. 1999:42:51-4.

14. Hypponen E, Laara E, Reunanen A, Jarvelin MR, Virtanin SM. Intake of vitamin D and risk of type 1 diabetes: a birth-cohort study. Lancet. 2001;358: 1500-3.

15. Fronczak CM, Baron AE, Chase HP, Ross C, Brady HL, Hoffman M, et al. In utero dietary exposures and risk of islet autoimmunity in children. Diabetes Care. 2003;26:3237-42.

16. Von Essen MR, Kongsbak M, Schjerling P, Olgaard K, Odum N, Geisler C. Vitamin D controls $T$ cell antigen receptor signaling and activation of human T cells. Nat Immunol. 2010;11(4):344-9.

17. Holick MF. Diabetes and the vitamin D connection. Curr Diab Rep. 2008;8: 393-8.

18. Levy-Marchal C, Patterson C, Green A, The EURODIAB Ace Study Group. Variation by age group and seasonality at diagnosis of childhood IDDM in Europe. Diabetologia. 1995;38:823-30.

19. Holick MF, Binkley NC, Bischoff-Ferrari H, Gordon CM, Hanley DA, Heaney $\mathrm{RP}$, et al. Evaluation, treatment, and prevention of vitamin D deficiency: an Endocrine Society clinical practices guideline. J Clin Endocrinol Metab. 2011; 96(7):1911-30.

20. Shah NM, Shah MA, Radovanovic Z. Social class and morbidity differences among Kuwaiti children. J Health Population Develop Countries. 1999:2:58-69.

21. Moussa MAA, Alsaeid M, Abdella N, Refai TMK, AL-Sheikh N, Gomez JE. Social and psychological characteristics of Kuwaiti children and adolescents with type 1 diabetes. Social Sci Med. 2005;60:1835-44.

22. AL-Daghri NM, AL-Attas OS, Alokail MS, Alkharfy KM, Yakout SM, Aljohani NJ, et al. Lower vitamin D status is more common among Saudi adults with diabetes mellitus type 1 than in non-diabetics. BMC Public Health. 2014;14: 153 (www.biomedcentral.com/1471-2458/14/153).

23. Bin-Abbas BS, Jabari MA, Issa SD, AL-Fares AH, AL-Muhsen S. Vitamin D levels in Saudi children with type 1 diabetes. Saudi Med J. 2011;32(6):589-92.

24. Svoren BM, Volkening LK, Wood JR, Laffel LM. Significant vitamin D deficiency in youth with type 1 diabetes mellitus. J Pediatr. 2009:154:132-4.

25. Greer R, Rogers M, Bowling F, Buntain H, Harris M, Leong G. Australian children and adolescents with type 1 diabetes have low vitamin D levels. Med J Aust. 2007;187:59-60.

26. Janner M, Ballinari $P$, Mullis PE. High prevalence of vitamin D deficiency in children and adolescents with type 1 diabetes. Swiss Med Wkly. 2010;140w: 13091.

27. Pozzilli P, Manfrini S, Crino A, Picardi A, Leomanni C, Cherubini V, et al. Low levels of 25-hydroxyvitamin D3 and 1,25 dihydroxyvitamin D3 in patients with newly diagnosed type 1 diabetes. Horm Metab Res. 2005; 37:680-3.

28. Bener A, Alsaeid A, AL-Ali M, AL-Kubaisi A, Basha B, Abrahan A, et al. High prevalence of vitamin $D$ deficiency in type 1 diabetes mellitus and healthy children. Acta Diabetol. 2009:46:183-9.

29. Bierschenk L, Alexander J, Wasserfall C, Haller M, Schatz D, Atkinson M. Vitamin D levels in subjects with and without type 1 diabetes residing in a solar rich environment. Diabetes Care. 2009;32:1977-9.
30. Littorin B, Blom P, Scholin A, Arnqvist HJ, Blohme G, Bolinder J, et al. Lower levels of plasma 25-hydroxyvitamin D among young adults at diagnosis of autoimmune type 1 diabetes compared with control subjects: results from the nationwide Diabetes Incidence Study in Sweden (DISS). Diabetologia. 2006:49:2847-52.

31. Borkar W, Devidayal VS, Bhalla AK. Low levels of vitamin D in North Indian children with newly diagnosed type 1 diabetes. Pediatr Diabetes. 2010;11: 345-50.

\section{Submit your next manuscript to BioMed Central and we will help you at every step:}

- We accept pre-submission inquiries

- Our selector tool helps you to find the most relevant journal

- We provide round the clock customer support

- Convenient online submission

- Thorough peer review

- Inclusion in PubMed and all major indexing services

- Maximum visibility for your research

Submit your manuscript at www.biomedcentral.com/submit

) Biomed Central 